\title{
Ketamine-New Possibilities in the Treatment of Depression: A Narrative Review
}

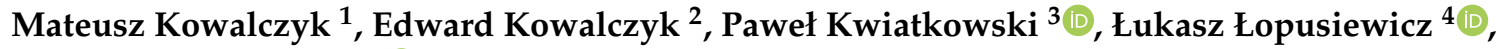 \\ Monika Sienkiewicz ${ }^{5, *(D)}$ and Monika Talarowska ${ }^{6}$
}

1 Babinski Memorial Hospital, Aleksandrowska St. 159, 91-229 Lodz, Poland; mateuszjerzykowalczyk@gmail.com

2 Department of Pharmacology and Toxicology, Medical University of Lodz, Żeligowskiego St. 7/9, 90-752 Lodz, Poland; edward.kowalczyk@umed.lodz.pl

3 Department of Diagnostic Immunology, Pomeranian Medical University in Szczecin, Powstańców Wielkopolskich 72, 70-111 Szczecin, Poland; pawel.kwiatkowski@pum.edu.pl

4 Center of Bioimmobilisation and Innovative Packaging Materials, Faculty of Food Sciences and Fisheries, West Pomeranian University of Technology Szczecin, Janickiego 35, 71-270 Szczecin, Poland; lukasz.lopusiewicz@zut.edu.pl

5 Department of Pharmaceutical Microbiology and Microbiological Diagnostic, Medical University of Lodz, Muszyńskiego St. 1, 90-151 Lodz, Poland

6 Department of Clinical Psychology and Psychopathology, Institute of Psychology, University of Lodz, Smugowa St. 10/12, 91-433 Lodz, Poland; monika.talarowska@now.uni.lodz.pl

* Correspondence: monika.sienkiewicz@umed.lodz.pl; Tel.: +48-42-272-55-60

Citation: Kowalczyk, M.; Kowalczyk E.; Kwiatkowski, P.; Łopusiewicz, Ł.; Sienkiewicz, M.; Talarowska, M. Ketamine-New Possibilities in the Treatment of Depression: A Narrative Review. Life 2021, 11, 1186. https:// doi.org/10.3390/life11111186

Academic Editor: Wenceslao Peñate

Received: 22 September 2021

Accepted: 31 October 2021

Published: 5 November 2021

Publisher's Note: MDPI stays neutral with regard to jurisdictional claims in published maps and institutional affiliations.

Copyright: (c) 2021 by the authors. Licensee MDPI, Basel, Switzerland. This article is an open access article distributed under the terms and conditions of the Creative Commons Attribution (CC BY) license (https:/ / creativecommons.org/licenses/by/ $4.0 /)$.

\begin{abstract}
The SARS-CoV-2 coronavirus epidemic has led to an increase in the number of people with depression. Symptoms related to the mental sphere (mainly depression and anxiety) may be experienced by one third of the worldwide population. This entails the need for the effective and rapid treatment of depressive episodes. An effective drug seems to be s-ketamine, which was accepted in March 2019 by the Food and Drug Administration (FDA) for the treatment of drugresistant depression. This drug provides a quick antidepressant effect with maximum effectiveness achieved after $24 \mathrm{~h}$. It also appears to reduce the occurrence of suicidal thoughts. However, research into undesirable effects, especially in groups of people susceptible to psychotic episodes or those who use alcohol or psychoactive substances, is necessary.
\end{abstract}

Keywords: ketamine; depression; anxiety; NMDA receptor; neurodegeneration; GABA; COVID-19 pandemic

\section{Introduction}

As of 1 May 2021, there were 153 million confirmed COVID-19 cases, and 3.2 million related deaths have been reported by the WHO. The regions of the Americas and Europe have been the most affected (almost half (48\%) of all reported COVID-19-associated deaths occurring in the Americas, and one third (34\%) in Europe) [1]. According to the World Health Organization, before the COVID-19 pandemic, approximately 350 million people worldwide were suffering from depression [2]. The worldwide distribution of so-called major depression (MD) or major depressive disorders (MDD) was estimated from 3\% in Japan to $16.9 \%$ in the USA; in most other countries the prevalence ranged between $8 \%$ and $12 \%[3,4]$.

The SARS-CoV-2 coronavirus epidemic has produced changes in these statistics for several months. According to the available data, symptoms related to the mental sphere (mainly depression and anxiety symptoms) may affect one third of the general population [5]. According to Santomauro et al., there has been an increase of $27.6 \%$ per 100,000 population cases of major depressive disorder globally due to the COVID-19 pandemic, with increases in North Africa and the Middle East of 37.2\%, in Latin America and the Caribbean of 37.8\%, and in Central Europe, Eastern Europe, and Central Asia of 29.4\%. 
The authors also estimated an increase of $25.6 \%$ per 100,000 population cases of anxiety disorders globally, mainly in South Asia, where an increase of $35.1 \%$ was noted, but also in North Africa and the Middle East, where there has been an increase of $32.4 \%$, in Latin America and the Caribbean, with an increase of 31.7\%, and in Central Europe, Eastern Europe, and Central Asia, with an increase of 30.0\% [6]. In a broader perspective, depressive disorders in the time of the COVID-19 pandemic have many negative consequences, both medical and sociological, and significantly reduce both quality of life and the adaptability of the individual [7].

Depression is a complex and heterogeneous disease, and its etiopathogenesis involves many factors at different psychological, biological, genetic and social levels [8]. Despite the great medical and social importance of MD, there is no clear concept behind its causes and the mechanism of its development. Several theories explaining the onset of depression have been proposed and confirmed by biochemical, immunological and physiological studies. In parallel to the well-known theories of depression ("monoamine", "cytokine", "stress" the hypothalamic-pituitary-adrenal (HPA) axis), other theories, including altered brain neural plasticity, neurogenesis and circadian desynchronosis (chronobiological model), have been proposed to explain the onset of MD symptoms [9,10].

A detailed understanding of the mechanisms underlying depression appears to be essential to provide an appropriate therapeutic approach in order to alleviate or arrest the disease. Guidelines for treating depression suggest selective serotonin reuptake inhibitors (SSRIs) and serotonin norepinephrine reuptake inhibitors (SNRIs) among other drugs, including agomelatine, bupropion, mirtazapine and vortioxetine as first-line drugs [11,12]. However, about one-third of depressed patients treated report little or no symptomatic improvement. This phenomenon often leads to discontinuation of therapy and deterioration in the quality of patients' lives and increases the risk of successful suicide attempts [13].

Over the past few years, ketamine has become more popular as a potential new drug in the pharmacotherapy of MD [14,15]. It has been successfully used as a general fast-acting anesthetic for a long time. Ketamine is a derivative of phencyclidine, a substance belonging to the group of psychodysleptic agents, also known as hallucinogens [16].

In March 2019, the Food and Drug Administration (FDA) approved the use of intranasal s-ketamine for the treatment of drug-resistant depression [17]. There have been more and more reports indicating the effectiveness of this substance in the therapy of so-called treatment-resistant depression (TRD) [18]. Bartoli et al. report that ketamine significantly reduces the frequency of suicidal thoughts in depressive patients [19]. McIntyre et al. state that intravenous ketamine is an effective antidepressant in people with the above-mentioned drug-resistant depression [20]. Will the N-methyl-D-aspartate (NMDA) receptor potentially be a new treatment target for depression [21]?

\section{Methodology}

An exhaustive review of the literature published up to October 2021 in PubMed (U.S. National Library of Medicine) was performed. Our search strategy combined the following terms: ketamine, depression, NMDA receptor, neurodegeneration, GABA. The full articles were downloaded, as well as books on the treatment of depression, to find possible additional related publications.

\section{N-Methyl-D-Aspartate (NMDA) Receptor}

The stimulating effect of amino acids on the activity of neurons was first described by Curtis in 1959 [22]. He showed a depolarizing effect of glutamic acid (GLU) on rat spinal neurons. Twenty consecutive years have been spent on research proving that GLU is one of the most important excitatory neurotransmitters in the central nervous system (CNS) [23], and that glutamate receptors are ubiquitous in the brain and spinal cord. There are three families of ionotropic glutamate receptors: $\mathrm{N}$-methyl-D-aspartate (NMDA) — the agonist is NMDA; $\alpha$-amino-3-hydroxy-5-methyl-4-isoxazole propionate (AMPA) - the agonist is AMPA; and kainic - stimulated by kainic acid. There are many binding points of the 
so-called competitive antagonists (the same site where GLU and NMDA bind) within the NMDA receptor [24,25].

At rest, the NMDA receptor is inactive due to the voltage-dependent blocking of the channel pores by magnesium ions. Unlike AMPA, NMDA receptors are non-selective for cations such as $\mathrm{Ca}^{2+}, \mathrm{Na}^{2+}$ and $\mathrm{K}^{2+}$ ions. $\mathrm{Ca}^{2+}$ influx is crucial for NMDA receptor induction. The influx of calcium into the cell activates calcium-dependent enzymes, stimulates the formation of free radicals and leads to swelling and cell death. It also leads to the release of a large amount of GLU, which is found in significant amounts in CNS cells. Glutamate outside the cell can depolarize cell membranes, damage subsequent cells and is responsible for the spread of the neurodegeneration process. This glutamate loop can increase the extent of damage after trauma, ischemia and encephalitis [26]. $\mathrm{Ca}^{2+} /$ calmodulin-mediated activation of the NMDA receptor also leads to the activation of nitrogen oxygen synthetase (NO), which plays a key role in nociception and neurotoxicity. The results of NMDA receptor activation are shown in Figure 1.

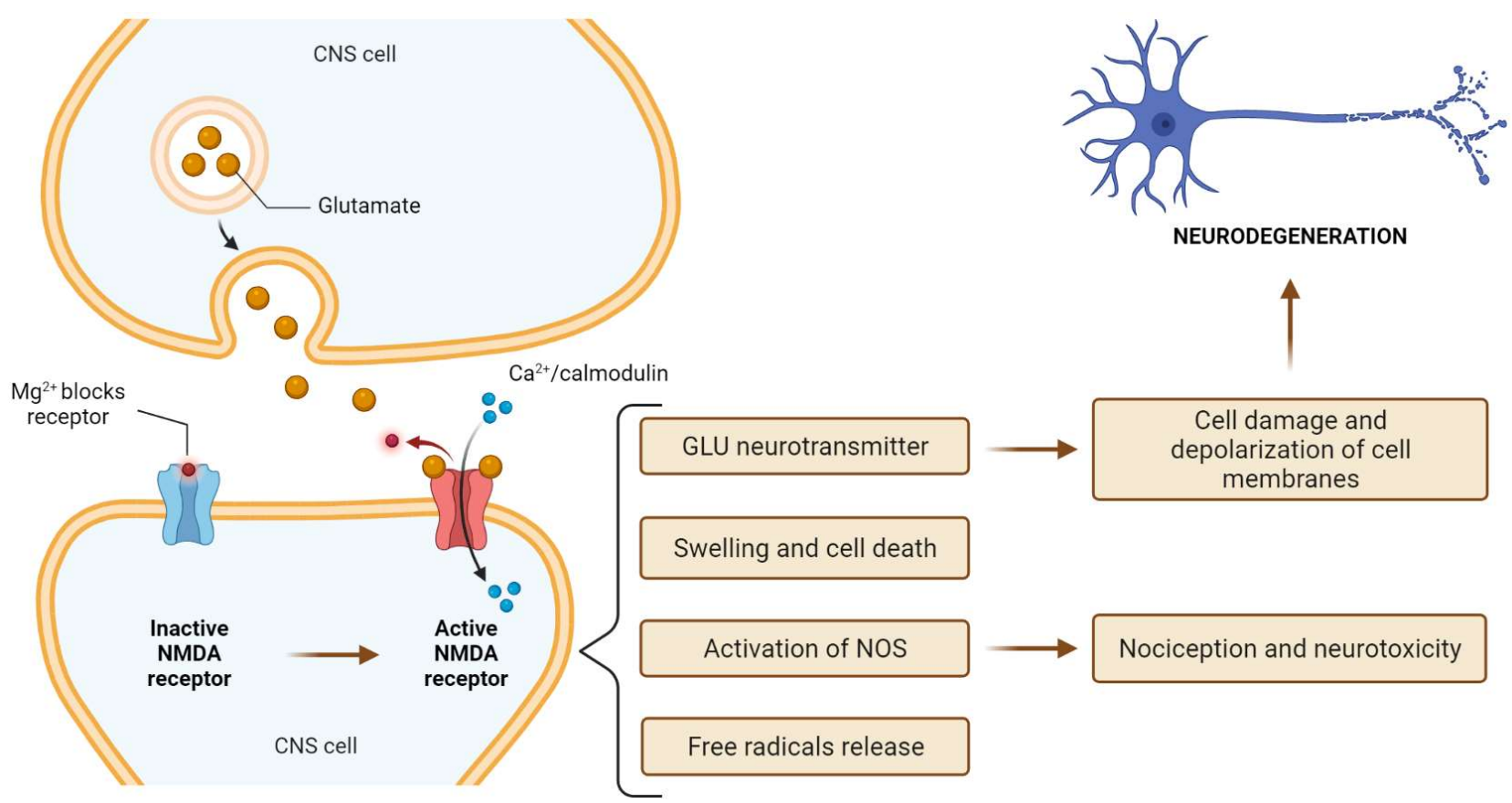

Figure 1. The effects of NMDA receptor activation. Created with BioRender.com (accessed on 1 September 2021).

Already in the 1950s, Lucas and Newhouse [27] presented the possible toxic effects of GLU on cells. However, the author of the concept of neurotoxicity of excitatory amino acids in the brain is Olney [28], who described the mechanism of excessive stimulation of NMDA receptors by GLU in the pathogenesis of various forms of nerve cell damage. He also drew attention to the role of NMDA receptors and the possibility of modulating the glutamatergic system function through antagonists of these receptors.

The functioning of the glutamatergic system determines the proper functioning of cognitive processes, memory and learning. The results of many studies indicate a relationship between the dysfunction of the glutamatergic system and neuroplasticity disorders and neurodegenerative processes in the course of Alzheimer's or Huntington's disease [29]. NMDA receptors are involved in global and focal ischemia and in various neurological diseases [30].

Scientific research confirms the involvement of the glutamatergic system in the processes of mood regulation. People suffering from depression showed a decreased level of this neuromediator in the cingulate cortex, with elevated levels in the occipital cortex. [31]. Dysfunction of AMPA receptors (including the decreased expression of mGlu3 subunits) in 
the prefrontal cortex and the increased expression of NMDA receptors were reported in patients suffering from affective disorders [32].

In addition, the glutamatergic system is involved in neuroplasticity processes, such as the formation and proper functioning of synapses, axon and dendrite cytoskeleton and in the maintenance of the level of neuromediators. It is possibly involved in all CNS functions [33-35]. The influence on the glutamatergic system is therefore the basis of intervention in many brain dysfunctions.

The renaissance in anesthetic ketamine as the first non-competitive NMDA receptor antagonist is currently noted. Non-competitive NMDA receptor antagonists act at a site other than the agonist recognition site by blocking the NMDA receptor in the channel in a usage-dependent manner (i.e., the channel must first be opened by the agonist in order to be bound to the antagonist).

New research also indicates other potential mechanisms of NMDA receptor antagonist action protecting against the progression of neurodegeneration. According to this work, for instance, amantadine may exhibit a double protective mechanism, completely independent of blocking the NMDA receptor and consisting in both the inhibition of microglia stimulation (and thus the inflammatory process) and the astroglial stimulation (thus the production of trophic factor (GDNF-glial derived neurotrophic factor)). Today, many researchers consider both of these phenomena, the microglia stimulation and reduction in trophic factors, as crucial in the processes of neurodegeneration and depression [36-38].

\section{Ketamine Characteristics}

Ketamine is a synthetic, non-barbiturate anesthetic synthesized by Calvin Stevens of the Parke-Davis Pharmaceutical Company in 1962 (Ann Arbor, MI, USA), which was looking for an alternative to the potent hallucinogenic agent phencyclidine [39,40].

Due to its rapid onset and short duration of action, with only minor cardio-respiratory depression compared to other general anesthetics, and possible use in maintaining anesthesia via inhalation, ketamine is the drug of choice for short-term surgery, especially in children, and is also used in veterinary medicine [41,42]. Ketamine produces dissociative anesthesia (i.e., a sense of separation from the body and surroundings) $[40,43]$. Under dissociative anesthesia, the patient remains awake and seems to be conscious (i.e., the eyes may be open with nystagmus present), but shows no response to surgical pain. $\mathrm{He} / \mathrm{she}$ is in complete analgesia and total amnesia, with reflex protection in the airways (intubation is not necessary), spontaneous breathing and cardiovascular stability (i.e., blood pressure and heart rate do not drop and may even increase slightly) [44]. The dissociative state appears to result from functional dissociation-inhibition of the thalamocortical pathways and stimulation of the limbic areas of the brain [45]. These neural systems help maintain the neural connections required for consciousness. Ketamine is also proposed as an effective pain reliever and a therapeutic agent in the treatment of alcoholism [46], heroin addiction [47] and anorexia [48]. It is recommended in the treatment of depression due to its long-lasting effects and quick onset of action (within four hours after administration) [49-52].

In 2000, Berman et al. demonstrated that a dose $(0.5 \mathrm{mg} / \mathrm{kg})$ of ketamine exerts a rapid and long-lasting antidepressant effect in patients with MDD [53]. Zarate et al. confirmed the rapid and long-lasting antidepressant effect of ketamine in patients with refractory MDD and found that ketamine reduces the tendency to have suicidal thoughts in patients with MDD [54]. Although ketamine has a strong antidepressant effect, its side effects may limit widespread use [55-57].

Ketamine ( $\mathrm{Ki}=0.53 \mu \mathrm{M}$ for NMDAR) racemic mixture with different proportions of (R)-ketamine and (S)-ketamine.

Binder affinity (S) of ketamine ( $\mathrm{Ki}=0.30 \mu \mathrm{M})$ to NMDAR is about four times stronger than $(\mathrm{R})$-ketamine $(\mathrm{Ki}=1.4 \mu \mathrm{M})$.

The anesthetic effect of (S)-ketamine is approximately three to four times stronger, but the psychomimetic side effects are greater than those of (R)-ketamine. Studies showed that (R)-ketamine has a stronger antidepressant effect than (S)-ketamine. Recent studies showed 
that the order of antidepressant effects after intranasal administration is: (R)-ketamine $>(\mathrm{R}, \mathrm{S})$-ketamine $>(\mathrm{S})$-ketamine; and that the order of adverse effects in rodents is (S)ketamine $>(\mathrm{R}, \mathrm{S})$-ketamine $>(\mathrm{R})$-ketamine. As was mentioned in the introduction, on 5 March, 2019, the US FDA approved (S)-ketamine nasal spray (Spravato ${ }^{\mathrm{TM}}$ ) for cases of treatment-resistant depression [58]. A clinical trial of (R)-ketamine and (2R, 6R)-HNK in humans is currently underway.

\section{Ketamine-The Receptor and Non-Receptor Mechanism of Action}

Ketamine has been known for many years as an antagonist of glutamate receptors [21]. Like phencyclidine, ketamine blocks the NMDA receptor in a non-competitive manner. It blocks the open channel and reduces the average channel open time. Ketamine also reduces the frequency of channel openings [59]. NMDA receptor antagonism is responsible for the specific properties of ketamine, such as amnesia and its psychosensory, analgesic and neuroprotective effects. Ketamine also has glutamate-independent effects. It interacts with many receptors, such as opioid, monoaminergic, cholinergic, nicotinic and muscarinic receptors. It potentiates the inhibitory effects of GABA (GABA-A complex) [60]. Ketamine binds to the $\mathrm{mu}$, delta and kappa opioid receptors. The affinity of $\mathrm{S}(+)$-ketamine for opioid receptors is two to three times higher than that of the $\mathrm{R}(-)$ isomer. The effect of ketamine on opioid receptors is not antagonized by naloxone [61].

Undoubtedly, its action on the monoaminergic system is important. Ketamine causes a hyperadrenergic state (i.e., stimulates noradrenergic neurons and inhibits the uptake of catecholamines, increasing the release of norepinephrine, dopamine and serotonin).

Inhibition of norepinephrine uptake is stereospecific, the $\mathrm{R}(-)$ isomer only inhibits its uptake by neurons, while the $S(+)$ isomer also inhibits extra neuron uptake. There is a prolonged synaptic action leading to an increased transfer of norepinephrine into the blood circulation [59]. Alpha-2 agonists are able to reduce this hyperadrenergic state and also the psychological phenomena caused by ketamine [62]. Due to its interaction with the serotonin transporter [63], ketamine also inhibits the uptake of dopamine and serotonin [64]. Some of the effects of ketamine include the purinergic system, such as urinary toxicity [65].

Ketamine interacts with sodium channels. It binds to the same site inside sodium channels as local anesthetics [66]. It is also effective as a topical pain reliever [67]. Moreover, ketamine inhibits neuronal potassium channels [68]. This mechanism may explain some of the neuroprotective properties of $S(+)$ isomers.

Several studies suggest that ketamine, through glutamate and/or neurotrophic receptors, stimulates the mammalian target of rapamycin (mTOR) pathway in the prefrontal cortex (PFC) $[51,69,70]$. mTOR is a threonine-serine protein kinase involved in cell proliferation, mortality, survival and protein synthesis [71], including the neurotrophic growth factor (BDNF) that binds to the neurotrophin receptor (TrkB). Studies showed that chronic ketamine treatment was able to counteract the decline in BDNF protein in the hippocampus and nucleus accumbens [72]. The process of antidepressant action of ketamine was shown in Figure 2.

Heise et al. demonstrated that ketamine increases the BDNF expression and exerts antidepressant effects in experimental animals, but not in knockout animals of the eukaryotic elongation factor $2 \mathrm{eEF} 2 \mathrm{~K}$ kinase [73]. eEF2K is a kinase important for the regulation of protein translation elongation [74]. Liu and Dumni believe that eEF2K can play a role in processes such as learning and memory, and in depression [75]. Ketamine activation of mTOR can be suppressed by rapamycin, a specific mTOR inhibitor. Rapamycin blocks ketamine-induced synaptogenesis and abolishes the antidepressant effect of ketamine [51]. 


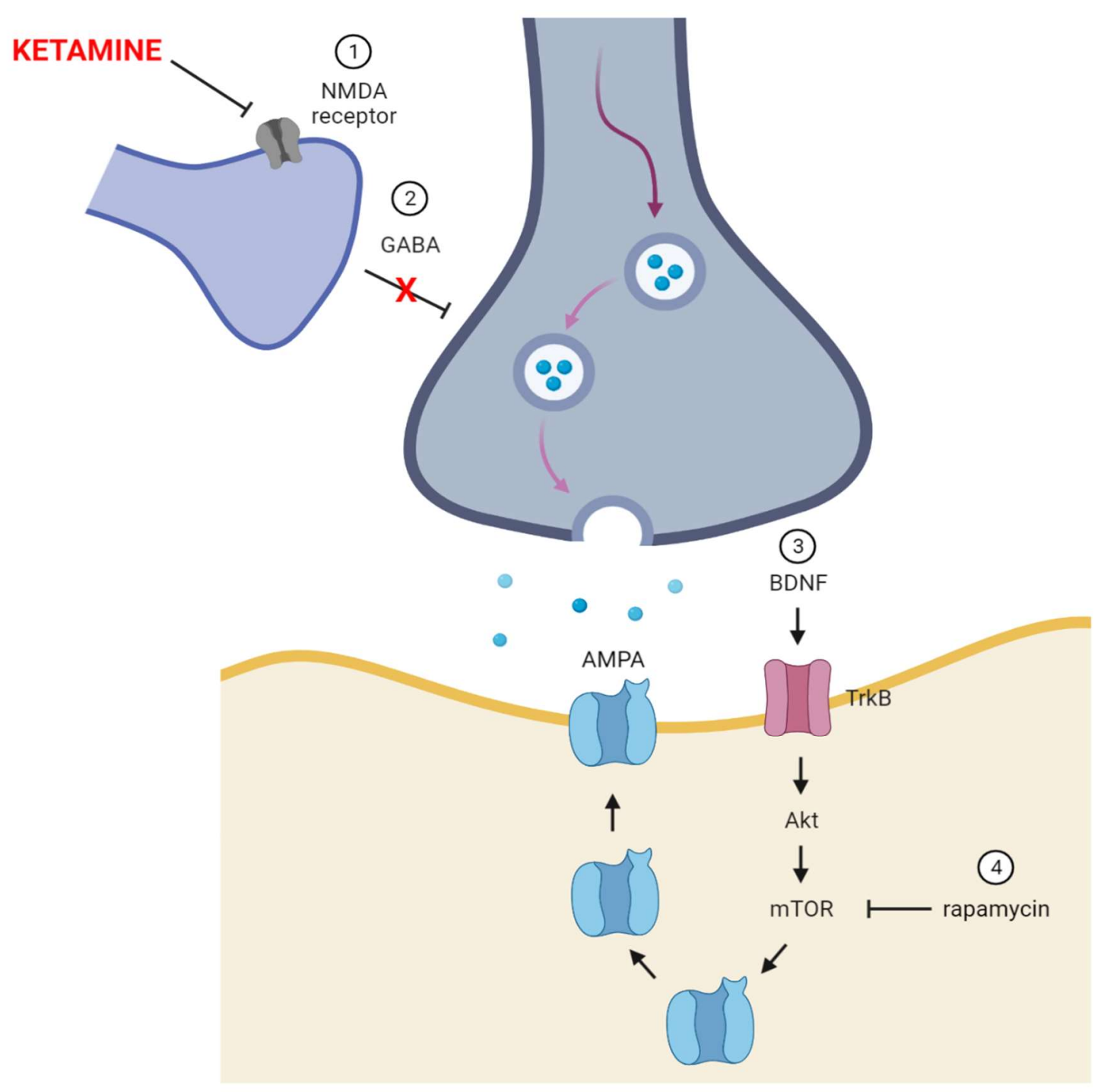

Figure 2. Mechanism of the antidepressant action of ketamine. Created with BioRender.com (accessed on 1 September 2021).

\section{Ketamine Toxicity}

Being an analog of phencyclidine, ketamine is ten times less potent and causes less severe dysphoria and hallucinations. Unfortunately, the psychomimetic effects made ketamine a popular party/club drug. It produces euphoric and dissociative effects at low doses and immobilizing and hallucinogenic effects at high doses.

The 2015 World Drug Report classified ketamine as a worldwide recreational drug. However, ketamine abuse is relatively minor, and phencyclidine derivatives account for only $1 \%$ of the "new psychoactive substances". This type of ketamine use often occurs in conjunction with other substances, including alcohol, amphetamines, MDMA, cocaine and caffeine. In the United States, the abuse of ketamine has increased since the 1980s. However, compared to the sharp increase in opioid abuse and the illegal abuse of cannabis, the abuse of ketamine is relatively small. Ketamine use is becoming increasingly popular as a recreational drug in Southeast Asian countries, such as Taiwan, Malaysia, and China [76].

Currently, there is little information on the toxicokinetics of ketamine in the human population. Gable estimated the mean lethal dose to be $600 \mathrm{mg} / \mathrm{kg}$, or $4.2 \mathrm{~g}$ for a $70 \mathrm{~kg}$ human, on average [77].

The symptoms of ketamine overdose are similar to those of phencyclidine overdose, although the effects of ketamine wear off more quickly. Physical signs and symptoms depend on the dose and interactions with other compounds taken at the same time. Gen- 
eral symptoms, including sedation and disturbed consciousness, may occur when using ketamine. In addition, horizontal, vertical or rotational nystagmus, pupil dilation and excessive salivation are observed. Moreover, cardiovascular symptoms, such as hypertension, tachycardia, palpitations, arrhythmias and chest pain, have been noted. Abdominal pain, tenderness, nausea and vomiting may occur. The neurological symptoms include an altered mental state (confusion), paranoia, dysphoria, restlessness, confusion, slurred speech, dizziness, ataxia, dysarthria, trismus and muscle stiffness. Less pain sensation affects the possibility of injuries occurring [78-80].

Usually, in patients with symptoms of ketamine poisoning, observation and, if necessary, symptomatic treatment are sufficient. The effects of ketamine poisoning usually last from $15 \mathrm{~min}$ to several hours depending on the dose, route of administration, metabolic capacity and intrinsic sensitivity to the effects of the drug [81].

Patients who are asymptomatic but report recent ketamine use should be followed up for six hours. Patients who experience mild symptoms of intoxication should be monitored for 1-2 $\mathrm{h}$ after the last symptoms have subsided. Monitoring includes observation of respiration and circulation because ketamine has the potential to cause cardiopulmonary disorders, especially when it is taken in combination with other medications.

There are no medications approved by the US Food and Drug Administration to treat ketamine overdose, but medications can help manage agitation and psychosis. Benzodiazepines, such as lorazepam and diazepam can relieve agitation, psychomimetic effects, hypertension, hyperthermia and seizures. Lorazepam is usually given at a dose of 2 to $4 \mathrm{mg}$ intravenously or intramuscularly, and diazepam is usually given intravenously at a dose of 5 to $10 \mathrm{mg}$. Butyrophenones, including haloperidol, have been used to treat psychotic and agitation episodes [81].

In hyperthermia, sedation is used, and when it is ineffective, cold compresses are applied. Drugs that help relieve symptoms include alpha-2 agonists, such as clonidine. Clonidine can treat or prevent the psychomimetic side effects of ketamine, increase hemodynamic stability by lowering blood pressure and provide synergism with the analgesic effect of ketamine [82,83]. Clonidine is usually administered at a dose of $2.5-5 \mathrm{mg} / \mathrm{kg}$ by oral administration. Atropine or glycopyrrolate can prevent and treat hypersalivation associated with ketamine use, while physostigmine can treat nystagmus and blurred vision. In turn, administration of crystalloids may improve hydration. Hemoperfusion and dialysis are usually unsuccessful in ketamine intoxication due to the large volume of ketamine distribution [80].

\section{Discussion}

Studies seem to confirm the effectiveness of using s-ketamine in MDD. In the longterm studies, the majority of patients responded to the treatment with $84 \mathrm{mg}$, and about one third of patients responded to $56 \mathrm{mg}$, given weekly or every other week. The results also suggest that s-ketamine reduces the risk of suicide [84-87]. The adverse dissociative symptoms occurred within about 30 to 40 min following its administration and subsided after two hours. The increase in blood pressure lasting 10 to $40 \mathrm{~min}$ was recorded, which usually subsided two hours after the drug was administered. Other side effects included dizziness, headache, dysgeusia, sedation and nausea. Only dizziness and nausea were dose dependent. The studies were carried out in groups of patients taking s-ketamine in a dose of $14 \mathrm{mg}, 28 \mathrm{mg}, 56 \mathrm{mg}$ and $84 \mathrm{mg}$ [88,89]. The most commonly reported side effects of s-ketamine in people with depression are dizziness $(67 \%)$, nausea $(37.5 \%)$, disturbance in attention (29.2\%) and fatigue (29.2\%) [85].

\section{Conclusions}

Ketamine is the first drug found to exert an impact on treatment-resistant depression with immediate effect. It also seems to reduce the occurrence of suicidal thoughts and provides a quick antidepressant effect with maximum effectiveness achieved after $24 \mathrm{~h}$. The efficacy and safety of its medium- and long-term use have not yet been well researched. 
Evidence from previous studies suggests that ketamine significantly reduces the severity of depression. However, extrapolation of these results should be attempted cautiously, as the patients included in the studies have not had a history of psychotic episodes or disorders related to the use of alcohol or psychoactive substances, which is not representative of all depressed patients who may benefit from this therapy.

Author Contributions: Conceptualization, M.K. and E.K.; formal analysis, M.T.; resources, E.K.; data curation, M.K. and M.S.; writing-original draft preparation, M.K., E.K. and M.T.; writing-review and editing, M.S.; visualization, M.S., P.K. and Ł.Ł.; supervision, M.T. All authors have read and agreed to the published version of the manuscript.

Funding: This research received no external funding.

Institutional Review Board Statement: Not applicable.

Informed Consent Statement: Not applicable.

Data Availability Statement: PubMed (U.S. National Library of Medicine).

Conflicts of Interest: The authors declare no conflict of interest.

\section{References}

1. World Health Statistics 2021: A Visual Summary. Available online: https://www.who.int/data/stories/world-health-statistics2021-a-visual-summary (accessed on 29 August 2021).

2. James, S.L.; Abate, D.; Abate, K.H.; Abay, S.M.; Abbafati, C.; Abbasi, N.; Abbastabar, H.; Abd-Allah, F.; Abdela, J.; Abdelalim, A.; et al. Global, Regional, and National Incidence, Prevalence, and Years Lived with Disability for 354 Diseases and Injuries for 195 Countries and Territories, 1990-2017: A Systematic Analysis for the Global Burden of Disease Study 2017. Lancet 2018, 392, 1789-1858. [CrossRef]

3. Rotenstein, L.S.; Ramos, M.A.; Torre, M.; Segal, J.B.; Peluso, M.J.; Guille, C.; Sen, S.; Mata, D.A. Prevalence of Depression, Depressive Symptoms, and Suicidal Ideation Among Medical Students: A Systematic Review and Meta-Analysis. JAMA 2016, 316, 2214-2236. [CrossRef] [PubMed]

4. La Torre, J.A.; Vilagut, G.; Ronaldson, A.; Serrano-Blanco, A.; Martín, V.; Peters, M.; Valderas, J.M.; Dregan, A.; Alonso, J. Prevalence and Variability of Current Depressive Disorder in 27 European Countries: A Population-Based Study. Lancet Public Health 2021. [CrossRef]

5. Guerrini, C.J.; Schneider, S.C.; Guzick, A.G.; Amos Nwankwo, G.N.; Canfield, I.; Fedson, S.; Gutierrez, A.M.; Sheu, J.C.; Song, A.Y.; Villagran, A.M.; et al. Psychological Distress among the U.S. General Population During the COVID-19 Pandemic. Front. Psychiatry 2021, 12, 810. [CrossRef]

6. Santomauro, D.F.; Mantilla Herrera, A.M.; Shadid, J.; Zheng, P.; Ashbaugh, C.; Pigott, D.M.; Abbafati, K.; Adolph, C.; Amlag, J.O.; Aravkin, A.; et al. Global prevalence and burden of depressive and anxiety disorders in 204 countries and territories in 2020 due to the COVID-19 pandemic. Lancet 2021, 8. [CrossRef]

7. Talarowska, M.; Chodkiewicz, J.; Nawrocka, N.; Miniszewska, J.; Biliński, P. Mental Health and the SARS-CoV-2 Epidemic-Polish Research Study. Int. J. Environ. Res. Public Health 2020, 17, 7015. [CrossRef]

8. Stupin, K.N.; Zenko, M.Y.; Rybnikova, E.A. Comparative Analysis of Pathobiochemical Changes in Major Depression and Post-Traumatic Stress Disorder. Biochemistry 2021, 86, 729-736. [CrossRef]

9. Ohayon, M.M.; McCue, M.; Krystal, A.; Chrones, L.; Touya, M.; Lawrence, D.; Patel, S.; Cote, M.L. A Longitudinal Study to Assess Antidepressant Treatment Patterns and Outcomes in Individuals with Depression in the General Population. CNS Spectr. 2021, 26, 180. [CrossRef]

10. Sarno, E.; Moeser, A.J.; Robison, A.J. Neuroimmunology of Depression. Adv. Pharmacol. 2021, 91, 259-292. [CrossRef]

11. Kennedy, S.H.; Lam, R.W.; McIntyre, R.S.; Tourjman, S.V.; Bhat, V.; Blier, P.; Hasnain, M.; Jollant, F.; Levitt, A.J.; MacQueen, G.M.; et al. Canadian Network for Mood and Anxiety Treatments (CANMAT) 2016 Clinical Guidelines for the Management of Adults with Major Depressive Disorder: Section 3. Pharmacological Treatments. Can. J. Psychiatry 2016, 61, 540-560. [CrossRef] [PubMed]

12. Lopizzo, N.; Zonca, V.; Cattane, N.; Pariante, C.M.; Cattaneo, A. MiRNAs in Depression Vulnerability and Resilience: Novel Targets for Preventive Strategies. J. Neural Transm. 2019, 126, 1241-1258. [CrossRef] [PubMed]

13. Yavi, M.; Henter, I.D.; Park, L.T.; Zarate, C. Key Considerations in the Pharmacological Management of Treatment-Resistant Depression. Expert Opin. Pharmacother. 2021, 1-11. [CrossRef] [PubMed]

14. Doty, R.L.; Popova, V.; Wylie, C.; Fedgchin, M.; Daly, E.; Janik, A.; Ochs-Ross, R.; Lane, R.; Lim, P.; Cooper, K.; et al. Effect of Esketamine Nasal Spray on Olfactory Function and Nasal Tolerability in Patients with Treatment-Resistant Depression: Results from Four Multicenter, Randomized, Double-Blind, Placebo-Controlled, Phase III Studies. CNS Drugs 2021, 35, 781-794. [CrossRef] [PubMed] 
15. Rosenblat, J.D.; Lipsitz, O.; Di Vincenzo, J.D.; Rodrigues, N.B.; Kratiuk, K.; Subramaniapillai, M.; Lee, Y.; Arekapudi, A.K.; Abrishami, A.; Chau, E.H.; et al. Real-World Effectiveness of Repeated Ketamine Infusions for Treatment Resistant Depression during the COVID-19 Pandemic. Psychiatry Res. 2021, 303, 114086. [CrossRef]

16. Ng, J.; Rosenblat, J.D.; Lui, L.M.W.; Teopiz, K.M.; Lee, Y.; Lipsitz, O.; Mansur, R.B.; Rodrigues, N.B.; Nasri, F.; Gill, H.; et al. Efficacy of Ketamine and Esketamine on Functional Outcomes in Treatment-Resistant Depression: A Systematic Review. J. Affect. Disord. 2021, 293, 285-294. [CrossRef]

17. Sanders, B.; Brula, A.Q. Intranasal Esketamine: From Origins to Future Implications in Treatment-Resistant Depression. J. Psychiatr. Res. 2021, 137, 29-35. [CrossRef]

18. Popova, V.; Daly, E.J.; Trivedi, M.; Cooper, K.; Lane, R.; Lim, P.; Mazzucco, C.; Hough, D.; Thase, M.E.; Shelton, R.C.; et al. Efficacy and Safety of Flexibly Dosed Esketamine Nasal Spray Combined With a Newly Initiated Oral Antidepressant in Treatment-Resistant Depression: A Randomized Double-Blind Active-Controlled Study. AJP 2019, 176, 428-438. [CrossRef]

19. Bartoli, F.; Riboldi, I.; Crocamo, C.; Di Brita, C.; Clerici, M.; Carrà, G. Ketamine as a Rapid-Acting Agent for Suicidal Ideation: A Meta-Analysis. Neurosci. Biobehav. Rev. 2017, 77, 232-236. [CrossRef]

20. McIntyre, R.S.; Rodrigues, N.B.; Lipsitz, O.; Nasri, F.; Gill, H.; Lui, L.M.; Subramaniapillai, M.; Kratiuk, K.; Teopiz, K.; Ho, R.; et al The Effectiveness of Intravenous Ketamine in Adults with Treatment-Resistant Major Depressive Disorder and Bipolar Disorder Presenting with Prominent Anxiety: Results from the Canadian Rapid Treatment Center of Excellence. J. Psychopharmacol. 2021, 35, 128-136. [CrossRef]

21. Irifune, M.; Shimizu, T.; Nomoto, M.; Fukuda, T. Ketamine-Induced Anesthesia Involves the N-Methyl-D-Aspartate ReceptorChannel Complex in Mice. Brain Res. 1992, 596, 1-9. [CrossRef]

22. Curtis, D.R.; Phillis, J.W.; Watkins, J.C. Chemical Excitation of Spinal Neurones. Nature 1959, 183, 611-612. [CrossRef] [PubMed]

23. Blandini, F.; Porter, R.H.; Greenamyre, J.T. Glutamate and Parkinson's Disease. Mol. Neurobiol. 1996, 12, 73-94. [CrossRef] [PubMed]

24. Watkins, J.C.; Krogsgaard-Larsen, P.; Honoré, T. Structure-Activity Relationships in the Development of Excitatory Amino Acid Receptor Agonists and Competitive Antagonists. Trends Pharmacol. Sci. 1990, 11, 25-33. [CrossRef]

25. Hirota, K.; Lambert, D.G. Ketamine: Its Mechanism(s) of Action and Unusual Clinical Uses. Br. J. Anaesth. 1996, 77, 441-444. [CrossRef]

26. Doble, A. Excitatory Amino Acid Receptors and Neurodegeneration. Therapie 1995, 50, 319-337. [PubMed]

27. Lucas, D.R.; Newhouse, J.P. The Toxic Effect of Sodium L-Glutamate on the Inner Layers of the Retina. AMA Arch. Ophthalmol. 1957, 58, 193-201. [CrossRef] [PubMed]

28. Kainic Acid as a Tool in Neurobiology; McGeer, P.L.; McGeer, E.G.; Olney, J.W. (Eds.) Raven Press: New York, NY, USA, 1978; ISBN 978-0-89004-279-3.

29. Zarate, C.A.; Du, J.; Quiroz, J.; Gray, N.A.; Denicoff, K.D.; Singh, J.; Charney, D.S.; Manji, H.K. Regulation of Cellular Plasticity Cascades in the Pathophysiology and Treatment of Mood Disorders: Role of the Glutamatergic System. Ann. N. Y. Acad. Sci. 2003, 1003, 273-291. [CrossRef] [PubMed]

30. Lindsley, C.W.; Shipe, W.D.; Wolkenberg, S.E.; Theberge, C.R.; Williams, D.L.; Sur, C.; Kinney, G.G. Progress towards Validating the NMDA Receptor Hypofunction Hypothesis of Schizophrenia. Curr. Top. Med. Chem. 2006, 6, 771-785. [CrossRef]

31. Altamura, C.; Maes, M.; Dai, J.; Meltzer, H.Y. Plasma Concentrations of Excitatory Amino Acids, Serine, Glycine, Taurine and Histidine in Major Depression. Eur. Neuropsychopharmacol. 1995, 5, 71-75. [CrossRef]

32. Beneyto, M.; Kristiansen, L.V.; Oni-Orisan, A.; McCullumsmith, R.E.; Meador-Woodruff, J.H. Abnormal Glutamate Receptor Expression in the Medial Temporal Lobe in Schizophrenia and Mood Disorders. Neuropsychopharmacology 2007, 32, 1888-1902. [CrossRef]

33. Collingridge, G.L.; Bliss, T.V. Memories of NMDA Receptors and LTP. Trends Neurosci. 1995, 18, 54-56. [CrossRef]

34. Collingridge, G.L.; Singer, W. Excitatory Amino Acid Receptors and Synaptic Plasticity. Trends Pharmacol. Sci. 1990, 11, 290-296. [CrossRef]

35. Danysz, W.; Parsons, C.; Bresink, I.; Quack, G. Glutamate in CNS Disorders-A Revived Target for Drug Development. Drug News Perspect. 1995, 8, 261-277.

36. Ossola, B.; Schendzielorz, N.; Chen, S.-H.; Bird, G.S.; Tuominen, R.K.; Männistö, P.T.; Hong, J.-S. Amantadine Protects Dopamine Neurons by a Dual Action: Reducing Activation of Microglia and Inducing Expression of GDNF in Astroglia [Corrected]. Neuropharmacology 2011, 61, 574-582. [CrossRef] [PubMed]

37. Allen, N.J.; Barres, B.A. Neuroscience: Glia-More than Just Brain Glue. Nature 2009, 457, 675-677. [CrossRef] [PubMed]

38. Smiałowska, M.; Szewczyk, B.; Woźniak, M.; Wawrzak-Wleciał, A.; Domin, H. Glial Degeneration as a Model of Depression. Pharmacol. Rep. 2013, 65, 1572-1579. [CrossRef]

39. Liu, Y.; Lin, D.; Wu, B.; Zhou, W. Ketamine Abuse Potential and Use Disorder. Brain Res. Bull. 2016, 126, 68-73. [CrossRef]

40. Domino, E.F.; Chodoff, P.; Corssen, G. Pharmacologic effects of CI-581, a new dissociative anesthetic, in man. Clin. Pharmacol. Ther. 1965, 6, 279-291. [CrossRef]

41. Hijazi, Y.; Bolon, M.; Boulieu, R. Stability of Ketamine and Its Metabolites Norketamine and Dehydronorketamine in Human Biological Samples. Clin. Chem. 2001, 47, 1713-1715. [CrossRef]

42. Fischer, M.M. Ketamine Hydrochloride in Severe Bronchospasm. Anaesthesia 1977, 32, 771-772. [CrossRef] 
43. Corssen, G.; Domino, E.F. Dissociative Anesthesia: Further Pharmacologic Studies and First Clinical Experience with the Phencyclidine Derivative CI-581. Anesth. Analg. 1966, 45, 29-40. [CrossRef]

44. Roberts, J.R.; Jerris, R. Hedges. In Roberts and Hedges' Clinical Procedures in Emergency Medicine, 6th ed.; Saunders: Philadelphia, PA, USA, 2013; ISBN 978-1-4557-0606-8.

45. White, P.F.; Way, W.L.; Trevor, A.J. Ketamine-Its Pharmacology and Therapeutic Uses. Anesthesiology 1982, 56, 119-136. [CrossRef] [PubMed]

46. Petrakis, I.L.; Limoncelli, D.; Gueorguieva, R.; Jatlow, P.; Boutros, N.N.; Trevisan, L.; Gelernter, J.; Krystal, J.H. Altered NMDA Glutamate Receptor Antagonist Response in Individuals with a Family Vulnerability to Alcoholism. Am. J. Psychiatry 2004, 161, 1776-1782. [CrossRef]

47. Krupitsky, E.M.; Burakov, A.M.; Dunaevsky, I.V.; Romanova, T.N.; Slavina, T.Y.; Grinenko, A.Y. Single versus Repeated Sessions of Ketamine-Assisted Psychotherapy for People with Heroin Dependence. J. Psychoact. Drugs 2007, 39, 13-19. [CrossRef]

48. Mills, I.H.; Park, G.R.; Manara, A.R.; Merriman, R.J. Treatment of Compulsive Behaviour in Eating Disorders with Intermittent Ketamine Infusions. QJM 1998, 91, 493-503. [CrossRef] [PubMed]

49. Murrough, J.W. Ketamine as a Novel Antidepressant: From Synapse to Behavior. Clin. Pharmacol. Ther. 2012, 91, 303-309. [CrossRef] [PubMed]

50. Duman, R.S.; Aghajanian, G.K. Synaptic Dysfunction in Depression: Potential Therapeutic Targets. Science 2012, 338 , 68-72. [CrossRef]

51. Li, N.; Lee, B.; Liu, R.-J.; Banasr, M.; Dwyer, J.M.; Iwata, M.; Li, X.-Y.; Aghajanian, G.; Duman, R.S. MTOR-Dependent Synapse Formation Underlies the Rapid Antidepressant Effects of NMDA Antagonists. Science 2010, 329, 959-964. [CrossRef] [PubMed]

52. Coyle, C.M.; Laws, K.R. The Use of Ketamine as an Antidepressant: A Systematic Review and Meta-Analysis. Hum. Psychopharmacol. 2015, 30, 152-163. [CrossRef]

53. Berman, R.M.; Cappiello, A.; Anand, A.; Oren, D.A.; Heninger, G.R.; Charney, D.S.; Krystal, J.H. Antidepressant Effects of Ketamine in Depressed Patients. Biol. Psychiatry 2000, 47, 351-354. [CrossRef]

54. Zarate, C.A.; Singh, J.B.; Carlson, P.J.; Brutsche, N.E.; Ameli, R.; Luckenbaugh, D.A.; Charney, D.S.; Manji, H.K. A Randomized Trial of an N-Methyl-D-Aspartate Antagonist in Treatment-Resistant Major Depression. Arch. Gen. Psychiatry 2006, 63, 856-864. [CrossRef]

55. Barash, P.G.; Cullen, B.F.; Stoelting, R.K.; Cahalan, M.K.; Stock, M.C.; Ortega, R. Clinical Anesthesia: Seventh Edition; Wolters Kluwer Health: Philadelphia, PA, USA, 2013; ISBN 978-1-4511-4419-2.

56. FRCA, K.; CENG, S.; FRCA, R.; FRCA, M. Introduction to Specialist Therapeutics. In Pharmacology E Pharmacokinetics; Springer: London, UK, 2010; pp. 53-66. ISBN 978-1-84996-145-5.

57. Niesters, M.; Martini, C.; Dahan, A. Ketamine for Chronic Pain: Risks and Benefits. Br. J. Clin. Pharmacol. 2014, 77, 357-367. [CrossRef] [PubMed]

58. SPRAVATO®(Esketamine) I SPRAVATO®. Available online: https://www.spravato.com/home-1 (accessed on 30 August 2021).

59. Kohrs, R.; Durieux, M.E. Ketamine: Teaching an Old Drug New Tricks. Anesth. Analg. 1998, 87, 1186-1193. [CrossRef]

60. Miller, K.W. The Nature of Sites of General Anaesthetic Action. Br. J. Anaesth. 2002, 89, 17-31. [CrossRef]

61. Hustveit, O.; Maurset, A.; Oye, I. Interaction of the Chiral Forms of Ketamine with Opioid, Phencyclidine, Sigma and Muscarinic Receptors. Pharmacol. Toxicol. 1995, 77, 355-359. [CrossRef] [PubMed]

62. Levänen, J.; Mäkelä, M.L.; Scheinin, H. Dexmedetomidine Premedication Attenuates Ketamine-Induced Cardiostimulatory Effects and Postanesthetic Delirium. Anesthesiology 1995, 82, 1117-1125. [CrossRef]

63. Martin, D.C.; Introna, R.P.; Aronstam, R.S. Inhibition of Neuronal 5-HT Uptake by Ketamine, but Not Halothane, Involves Disruption of Substrate Recognition by the Transporter. Neurosci. Lett. 1990, 112, 99-103. [CrossRef]

64. Martin, L.L.; Bouchal, R.L.; Smith, D.J. Ketamine Inhibits Serotonin Uptake in Vivo. Neuropharmacology 1982, $21,113-118$. [CrossRef]

65. Meng, E.; Chang, H.-Y.; Chang, S.-Y.; Sun, G.-H.; Yu, D.-S.; Cha, T.-L. Involvement of Purinergic Neurotransmission in Ketamine Induced Bladder Dysfunction. J. Urol. 2011, 186, 1134-1141. [CrossRef] [PubMed]

66. Wagner, L.E.; Gingrich, K.J.; Kulli, J.C.; Yang, J. Ketamine Blockade of Voltage-Gated Sodium Channels: Evidence for a Shared Receptor Site with Local Anesthetics. Anesthesiology 2001, 95, 1406-1413. [CrossRef] [PubMed]

67. Finch, P.M.; Knudsen, L.; Drummond, P.D. Reduction of Allodynia in Patients with Complex Regional Pain Syndrome: A Double-Blind Placebo-Controlled Trial of Topical Ketamine. Pain 2009, 146, 18-25. [CrossRef]

68. Friederich, P.; Urban, B.W. Interaction of Intravenous Anesthetics with Human Neuronal Potassium Currents in Relation to Clinical Concentrations. Anesthesiology 1999, 91, 1853-1860. [CrossRef] [PubMed]

69. Proescholdt, M.; Heimann, A.; Kempski, O. Neuroprotection of S(+) Ketamine Isomer in Global Forebrain Ischemia. Brain Res. 2001, 904, 245-251. [CrossRef]

70. Pałucha-Poniewiera, A.; Szewczyk, B.; Pilc, A. Activation of the MTOR Signaling Pathway in the Antidepressant-like Activity of the MGlu5 Antagonist MTEP and the MGlu7 Agonist AMN082 in the FST in Rats. Neuropharmacology 2014, 82, 59-68. [CrossRef] [PubMed]

71. Hay, N.; Sonenberg, N. Upstream and Downstream of MTOR. Genes Dev. 2004, 18, 1926-1945. [CrossRef]

72. Réus, G.Z.; Nacif, M.P.; Abelaira, H.M.; Tomaz, D.B.; dos Santos, M.A.B.; Carlessi, A.S.; Matias, B.I.; da Luz, J.R.; Steckert, A.V.; Jeremias, G.C.; et al. Ketamine Treatment Partly Reverses Alterations in Brain Derived- Neurotrophic Factor, Oxidative Stress and 
Energy Metabolism Parameters Induced by an Animal Model of Depression. Curr. Neurovasc. Res. 2015, 12, 73-84. [CrossRef] [PubMed]

73. Heise, C.; Gardoni, F.; Culotta, L.; di Luca, M.; Verpelli, C.; Sala, C. Elongation Factor-2 Phosphorylation in Dendrites and the Regulation of Dendritic MRNA Translation in Neurons. Front. Cell Neurosci. 2014, 8, 35. [CrossRef]

74. Monteggia, L.M.; Gideons, E.; Kavalali, E.T. The Role of Eukaryotic Elongation Factor 2 Kinase in Rapid Antidepressant Action of Ketamine. Biol. Psychiatry 2013, 73, 1199-1203. [CrossRef] [PubMed]

75. Liu, R.; Proud, C.G. Eukaryotic Elongation Factor 2 Kinase as a Drug Target in Cancer, and in Cardiovascular and Neurodegenerative Diseases. Acta Pharmacol. Sin. 2016, 37, 285-294. [CrossRef]

76. Daly, E.; Trivedi, M.; Janik, A. A randomized withdrawal, double-blind, multicenterstudy of esketamine nasal spray plus an oral antidepressant for relapse prevention in treatment-resistant depression. In Proceedings of the American Society of Clinical Psychopharmacology Annual Meeting, Miami, FL, USA, 29 May-1 June 2018.

77. Daly, E.J.; Singh, J.B.; Fedgchin, M.; Cooper, K.; Lim, P.; Shelton, R.C.; Thase, M.E.; Winokur, A.; Van Nueten, L.; Manji, H.; et al. Efficacy and Safety of Intranasal Esketamine Adjunctive to Oral Antidepressant Therapy in Treatment-Resistant Depression: A Randomized Clinical Trial. JAMA Psychiatry 2018, 75, 139-148. [CrossRef]

78. Nierenberg, A.A.; Husain, M.M.; Trivedi, M.H.; Fava, M.; Warden, D.; Wisniewski, S.R.; Miyahara, S.; Rush, A.J. Residual Symptoms after Remission of Major Depressive Disorder with Citalopram and Risk of Relapse: A STAR ${ }^{*} \mathrm{D}$ Report. Psychol. Med. 2010, 40, 41-50. [CrossRef]

79. Li, N.; Liu, R.-J.; Dwyer, J.M.; Banasr, M.; Lee, B.; Son, H.; Li, X.-Y.; Aghajanian, G.; Duman, R.S. Glutamate N-Methyl-D-Aspartate Receptor Antagonists Rapidly Reverse Behavioral and Synaptic Deficits Caused by Chronic Stress Exposure. Biol. Psychiatry 2011, 69, 754-761. [CrossRef]

80. Gable, R.S. Acute Toxic Effects of Club Drugs. J. Psychoact. Drugs 2004, 36, 303-313. [CrossRef] [PubMed]

81. Ben-Shlomo, I.; Rosenbaum, A.; Hadash, O.; Katz, Y. Intravenous Midazolam Significantly Enhances the Lethal Effect of Thiopental but Not That of Ketamine in Mice. Pharmacol. Res. 2001, 44, 509-512. [CrossRef]

82. Hansen, G.; Jensen, S.B.; Chandresh, L.; Hilden, T. The Psychotropic Effect of Ketamine. J. Psychoact. Drugs 1988, $20,419-425$. [CrossRef] [PubMed]

83. Orhurhu, V.J.; Vashisht, R.; Claus, L.E.; Cohen, S.P. Ketamine Toxicity. In StatPearls; StatPearls Publishing: Treasure Island, FL, USA, 2021.

84. Bokor, G.; Anderson, P.D. Ketamine: An Update on Its Abuse. J. Pharm. Pract. 2014, 27, 582-586. [CrossRef]

85. Sollazzi, L.; Modesti, C.; Vitale, F.; Sacco, T.; Ciocchetti, P.; Idra, A.S.; Tacchino, R.M.; Perilli, V. Preinductive Use of Clonidine and Ketamine Improves Recovery and Reduces Postoperative Pain after Bariatric Surgery. Surg. Obes. Relat. Dis. 2009, 5, 67-71. [CrossRef] [PubMed]

86. Cohen, S.P.; Bhatia, A.; Buvanendran, A.; Schwenk, E.S.; Wasan, A.D.; Hurley, R.W.; Viscusi, E.R.; Narouze, S.; Davis, F.N.; Ritchie, E.C.; et al. Consensus Guidelines on the Use of Intravenous Ketamine Infusions for Chronic Pain From the American Society of Regional Anesthesia and Pain Medicine, the American Academy of Pain Medicine, and the American Society of Anesthesiologists. Reg. Anesth. Pain Med. 2018, 43, 521-546. [CrossRef] [PubMed]

87. Morrison, R.L.; Fedgchin, M.; Singh, J.; Van Gerven, J.; Zuiker, R.; Lim, K.S.; van der Ark, P.; Wajs, E.; Xi, L.; Zannikos, P.; et al. Effect of Intranasal Esketamine on Cognitive Functioning in Healthy Participants: A Randomized, Double-Blind, Placebo-Controlled Study. Psychopharmacology 2018, 235, 1107-1119. [CrossRef]

88. Popova, V.; Daly, E.; Trivedi, M. Randomized, Double-Blind Study of Flexiblydosed Intranasal Esketamine plus Oral Antidepressant vs. Active Control in Treatment-Resistant Depression. In Proceedings of the American Psychiatric Association Annual Meeting, New York, NY, USA, 5-9 May 2018.

89. Ochs-Ross, R.; Daly, E.J.; Yun, Z.; Lane, R.; Lim, P.; Foster, K.; Hough, D.; Manji, H.; Drevets, W.C.; Sanacora, G.; et al. Efficacy and Safety of Intranasal Esketamine plus an Oral Antidepressant in Elderly Patients with Treatment-Resistant Depression. In Proceedings of the American Psychiatric Association Annual Meeting, New York, NY, USA, 5-9 May 2018. 